\title{
Text Credits \\ Copyrights des textes
}

p. 7 (c) Audrey Azoulay

pp. 149-152, 156-157 (C) Paul Lengrand - UNESCO

pp. 160, 162, 164, 166, 168 @ David Seymour - courtesy Mattia Acetoso

pp. 170-177 (C) Carlo Levi - UNESCO

pp. 181-188 (C) Giovanna Hendel

pp. 198-220 @ Juri Meda

pp. 245-252 (C) Carole Naggar

pp. 263-274 ( ) Karin Priem

English-French translations / traduction anglais-français: (C) Carole Naggar

French-English translations / traduction français-anglais: ( Coryn Lang 
This publication, the first volume in the series Appearances: Studies in Visual Research, also marks the start of a new book series by UNESCO entitled UNESCO Archives: Treasures Within. The present first volume of both book series derives from a successful collaboration between the editors of UNESCO Archives: Treasures Within and Appearances: Studies in Visual Research.

Cette publication, le premier volume de la série Appearances : Studies in Visual Research, marque également le début d'une nouvelle série d'ouvrages de l'UNESCO intitulée Archives de l'UNESCO : trésors d'archives. Le présent premier volume de deux séries d'ouvrages est le fruit d'une collaboration fructueuse entre les éditrices et éditeurs de Archives de l'UNESCO : trésors d'archives and Appearances : Studies in Visual Research. 